\title{
Perilaku Masyarakat di Ruang Terbuka Publik Alun- Alun Kabupaten Blora
}

\author{
Community Behavior in Public Open Space of Blora District Square
}

\author{
Septyani Wahyu Pradani ${ }^{1}$ dan Nurini ${ }^{1}$
}

Diterima: 14 September 2018 Disetujui: 17 Oktober 2018

\begin{abstract}
Keberadaan ruang terbuka publik di pusat kota dapat dimanfaatkan untuk meningkatan kualitas lingkungan dan hubungan sosial masyarakat. Hubungan sosial masyarakat dapat dilihat dari interaksi antar individu dalam menggunakan ruang yang membentuk pola perilaku. Dengan demikian, perkembangan ruang publik dapat dilihat dari perilaku masyarakat yang menggunakannya. Alun-alun Kabupaten Blora merupakan salah satu ruang terbuka publik di pusat Kabupaten Blora, yang memiliki peran penting sebagai penyedia ruang sosio-kultural untuk mewadahi berbagai macam aktivitas masyarakat. Untuk mengetahui pengaruh penyediaan ruang terhadap perilaku pengunjung, maka perlu adanya penelitian mengenai perilaku masyarakat di Alun-alun Kabupaten Blora. Penelitian ini bertujuan untuk mengidentifikasi perilaku masyarakat dalam menggunakan Alun-alun Kabupaten Blora sebagai ruang terbuka publik. Analisis dalam penelitian ini terdiri dari analisis karakteristik pengunjung, analisis karakteristik aktivitas, analisis pola pergerakan, serta analisis perilaku. Metode yang digunakan dalam penelitian ini adalah metode deskriptif kuantitatif dan kualitatif dengan teknik analisis statistik deskriptif dan behavior setting. Analisis behavior setting digunakan untuk mengetahui pola pergerakan dengan teknik placecentered mapping dan person-centered mapping. Subjek penelitian ini adalah pengguna alunalun Kabupaten Blora. Teknik sampling yang digunakan adalah Probability Sampling. Hasil penelitian ini diharapkan dapat memberikan rekomendasi terkait peningkatan kualitas ruang di alun-alun Kabupaten Blora agar terbentuk pola perilaku yang lebih baik.
\end{abstract}

Keyword: Ruang Terbuka Publik, Lingkungan, Perilaku, Behavior Setting

Abstract: The existence of public open spaces in the city center can be used to improve the quality of the environment and social relations of the community. Community social relations can be seen from the interaction between individuals in using space that shapes behavior patterns. Thus, the development of public space can be seen from the behavior of the people around. Blora District Square is one of the public open spaces in the center of Blora Regency, which has an important role as a provider of socio-cultural space to accommodate various kinds of community activities. To determine the effect of providing space on visitor behavior, it is necessary to conduct research on community behavior in Blora District Square. This study aims to identify community behavior in using Blora District Square as a public open space. The analysis in this study consisted of visitor characteristics, activity characteristics, movement patterns, and behavior analysis. The method used in this study is descriptive quantitative and qualitative methods with descriptive statistical and Behavior Setting analysis techniques. Behavior setting analysis is used to determine the movement pattern with place-centered mapping and person-centered mapping techniques. The subject of this study is the user of Blora Regency square. The sampling technique used is

\footnotetext{
${ }^{1}$ Departemen Perencanaan Wilayah dan Kota, Fakultas Teknik, Universitas Diponegoro
} 
Probability Sampling. The results of this study are expected to provide recommendations related to the improvement of the quality of space in Blora Regency square in order to form better behavior patterns.

Keywords: Public Open Space, Environment, Behavior, Behavior Setting

\section{PENDAHULUAN}

Manusia dan ruang merupakan dua hal yang tidak bisa terpisahkan karena keduanya saling berhubungan satu sama lain. Segala kegiatan yang dilakukan manusia di dalam ruang menghasilkan perilaku. Perilaku manusia pada hakikatnya adalah aktivitas dari manusia, baik yang dapat diamati secara langsung maupun tidak langsung, perilaku dapat terjadi apabila ada rangsangan, dimana suatu rangsangan tertentu akan menghasilakan reaksi berupa perilaku (Notoadmodjo, 2007). Banyak jenis perilaku masyarakat yang dapat ditemukan di ruang publik, karena interaksi antar manusia banyak berlangsung di ruang pubik (Liao et al., 2012). Ketersediaan ruang terbuka publik merupakan salah satu aspek penting yang harus diperhatikan dalam penataan ruang perkotaan. Ruang terbuka publik berperan sebagai salah satu elemen untuk meningkatkan kualitas hidup dan meningkatkan pembangunan perkotaan (Vertelj Nared \& Zavodnik Lamovšek, 2015). Pada prakteknya, buruknya kualitas ruang terbuka publik seringkali menjadi masalah di berbagai wilayah di Indonesia.

Alun-alun merupakan salah satu jenis ruang terbuka publik yang hidup. Ruang terbuka publik yang hidup berarti tidak hanya keberadaannya secara fisik, melainkan pula di dalamnya dapat dimanfaatkan untuk aktivitas dan interaksi sosial yang sesuai dengan jenis kegunaan ruangnya. Alun-alun Kabupaten Blora dikelilingi oleh bangunan-bangunan penting yang fungsional, yakni; Kantor Bupati, Masjid Agung, Sekolah, Situs Religi, Bank, dan gedung serbaguna skala perkotaan. Banyak aktivitas yang berlangsung di Alun-alun Kabupaten Blora setiap harinya, dari pagi hari sampai dengan malam hari. Pada saat malam hari hampir selalu ramai dikunjungi khususnya oleh keluarga dan muda mudi untuk berkumpul, terlebih lagi pada saat akhir pekan. Pada saat pagi hari sering digunakan untuk olahraga, terlebih pada saat hari minggu pagi terdapat kegiatan car free day (CFD) yang membuat jumlah pengunjung lebih banyak dari hari biasanya. Banyak pula acara-acara penting yang diselenggarakan di tempat tersebut, yakni upacara hari kemerdekaan, acara penting dengan tatanan panggung, dan lain sebagainya.

Dalam praktiknya, terdapat beberapa masalah baik fisik maupun non fisik yang terkait dengan perilaku manusia yang melakukan aktivitas di dalam area Alun-alun Kabupaten Blora. Tidak terdapat area khusus parkir yang pasti bagi para pengunjungnya, sehingga pengunjung cenderung memarkirkan kendaraan di bahu jalan. Terdapat pula beberapa masalah seperti jalur pejalan kaki yang sering digunakan untuk berjualan khususnya pada malam hari, kondisi sarana prasarana penunjang yang kurang baik dan kurang memadai, serta banyaknya pengamen/pengemis yang sering ada pada saat alunalun ramai pengunjung. Hal-hal tersebut berkaitan dengan sistem pengelolaan yang melibatkan pemerintah Kabupaten Blora serta pengunjung sebagai pengguna. Permasalahan ruang dapat mempengaruhi pola perilaku manusia, atau bahkan sebaliknya, permasalahan tersebut muncul sebagai dampak dari adanya pola perilaku tertentu. Oleh karena itu, untuk mengetahui pengaruh antara perilaku manusia dengan ruang, maka perlu dilakukan identifikasi perilaku masyarakat di ruang terbuka publik Alun-alun Kabupaten Blora. Dengan harapan dapat menyimpulkan bagaimana perilaku masyarakat sebagai pengguna alun-alun dalam menggunakan ruang yang telah disediakan, serta dapat memberikan rekomendasi yang tepat bagi pengelolaan alun-alun pada masa mendatang untuk meningkatkan kualitas layanannya. 
Berdasarkan latar belakang tersebut, perilaku manusia tidak terlepas dari lingkungan atau ruang yang menampung segala jenis kegiatan yang dilakukan manusia. Dalam studi kasus di Kabupaten Blora, sebagai ruang terbuka publik, alun-alun berfungsi sebagai tempat dilaksanakannya berbagai kegiatan masyarakat sebagai pengguna yang mengunjungi alun-alun. Dari kondisi tersebut dalam penelitian ini muncul suatu rumusan masalah "Bagaimana perilaku masyarakat di ruang terbuka publik Alun-alun Kabupaten Blora?”

\section{Ruang Publik}

Dalam UU No 26 Tahun 2007 tentang Penataan Ruang, disebutkan bahwa ruang adalah wadah yang meliputi ruang darat, ruang laut, dan ruang udara, termasuk ruang di dalam bumi sebagai satu kesatuan wilayah, tempat manusia dan makhluk lain hidup, melakukan kegiatan, dan memelihara kelangsungan hidupnya. Berdasarkan jenis penggunaannya, ruang dibedakan menjadi ruang privat dan ruang publik. Ruang privat merupakan ruang yang didalamnya hanya diperuntukkan bagi individu tertentu, sedangkan ruang publik bebas dimasuki oleh publik dengan kriteria tertentu.

\section{Ruang Terbuka Publik}

Ruang terbuka publik merupakan wadah bagi aktivitas sosial yang berfungsi melayani dan juga mempengaruhi kehidupan masyarakat kota. Ruang terbuka juga merupakan wadah dari kegiatan fungsional maupun aktivitas ritual yang mempertemukan sekelompok masyarakat dalam rutinitas normal kehidupan sehari-hari maupun dalam kegiatan periodik (Carr, 1992).

Secara umum, tujuan disediakannya ruang terbuka publik (Carr, 1992) dalam (Damayanty, N., Izziah, \& Anggraini, 2018) adalah sebagai berikut:

1) Kesejahteraan masyarakat

Kesejahteraan masyarakat menjadi motivasi dasar dalam penciptaan dan pengembangan ruang terbuka publik yang menyediakan jalur untuk pergerakan, pusat komunikasi, dan tempat untuk merasa bebas dan santai.

2) Peningkatan visual (visual enhancement)

Keberadaan ruang publik disuatu kota akan meningkatkan kualitas visual kota tersebut menjadi lebih manusiawi, harmonis dan indah.

3) Peningkatan lingkungan (environmental enhancement)

Penghijauan pada suatu ruang terbuka publik sebagai sebuah nilai estetika juga paruparu kota yang memberikan udara segar di tengah-tengah polusi.

4) Pengembangan ekonomi (economic development)

Pengembangan ekonomi adalah tujuan yang umum dalam penciptaan dan pengembangan ruang terbuka publik.

5) Peningkatan kesan (image Enhancement)

Merupakan tujuan yang tidak tertulis secara jelas dalam kerangka penciptaan suatu ruang terbuka publik namun selalu ingin dicapai.

\section{Fungsi RTH}

Terdapat empat fungsi RTH yaitu fungi ekologi, fungsi sosial budaya, fungsi ekonomi dan fungsi estetika. Fungsi ekologi sebagai pengatur iklim mikri yang berdampak pada lancarnya sirkulasi udara dan air secara alami, sebagai peneduh dan menghasilkan oksigen. Fungsi sosial dan budaya sebagai media komunikasi warga, tempat rekreasi dan wadah objek pendidikan. Fungsi ekonomi RTH memiliki peran dalam kaitannya usaha pertanian dan perkebunan. RTH juga memiliki fungsi estetika yaitu meningkatkan kenyamanan, memperindah lingkungan dan menciptakan suasana serasi (Permen PU No.5, 2008) 


\section{Perilaku}

Perilaku pada umumnya dimotivasi oleh suatu keinginan untuk mencapai tujuan tertentu, dimana tujuan spesifik tersebut tidak selalu diketahui secara sadar oleh individu yang bersangkutan (Winardi, 2004). Perilaku manusia pada hakikatnya adalah aktivitas dari manusia, baik yang dapat diamati secara langsung maupun tidak langsung, perilaku dapat terjadi apabila ada rangsangan, dimana suatu rangsangan tertentu akan menghasilakan reaksi perilaku tertentu (Notoadmodjo, 2007). Perilaku erat kaitannya terhadap hubungan manusia dengan lingkungannya.

Menurut Wesiman (1981) dalam (Effendi, D., Waani, J. O., \& Sembel, 2016), atribut perilaku yang muncul dari adanya interaksi dapat dirinci menjadi 12 (dua belas) yaitu:

a) Kenyamanam (comfort)

Kenyamanan adalah keadaan lingkungan yang memberikan rasa yang sesuai kepada pancaindera dan antropometrik disertai oleh fasilitas-fasilitas yang sesuai dengan kegiatannya.

b) Sosialitas (sociality)

Sosialitas adalah tingkat kemampuan seseorang dalam melaksanakan hubungan sosial di suatu setting.

c) Visibilitas (visibility)

Visibilitas adalah kemampuan untuk dapat melihat jelas tanpa terhalang secara visual pada objek yang dituju.

d) Aksesibilitas (accessibility)

Aksesibilitas adalah kemudahan bergerak melalui dan menggunakan lingkungan.

Kemudahan bergerak yang dimaksud adalah berkaitan dengan sirkulasi (jalan) dan visual (tampilan fisik sirkulasi).

e) Adaptabilitas (adaptability)

Adaptabilitas adalah kemampuan lingkungan untuk dapat menampung perilaku berbeda yang belum ada sebelumnya.

f) Rangsangan inderawi (sensory stimulation)

Rangsangan inderawi adalah kualitas dan intensitas perangsang sebagai pengalaman yang dirasakan oleh indera manusia.

g) Kontrol (control)

Kontrol adalah kondisi suatu lingkungan untuk mewujudkan personalitas menciptakan teritori serta membatasi suatu ruang dengan ruang lainnya.

h) Aktivitas (activity)

Aktivitas adalah perasaan adanya intensitas pada perilaku yang terus menerus terjadi di dalam suatu lingkungan.

i) Kesesakan (crowdedness)

Kesesakan adalah perasaan tingkat kepadatan (density) di dalam suatu lingkungan.

j) Privasi (privacy)

Privasi adalah kemampuan untuk memonitori jalannya informasi yang terlihat dan terdengar baik dari atau di suatu lingkungan. Privasi adalah keinginan atau kecenderungan pada diri seseorang untuk tidak diganggu kesendiriannya.

k) Makna (meaning)

Makna adalah kemampuan suatu lingkungan menyajikan makna-makna individual atau kebudayaan bagi manusia.

1) Legibilitas (legibility)

Legibilitas adalah suatu kemudahan bagi seseorang untuk dapat mengenal atau memahami elemen-elemen kunci dan hubungan dalam suatu lingkungan yang menyebabkan orang tersebut menemukan jalan atau arah yang tepat. 


\section{Tata Perilaku}

Behavior setting atau tata perilaku berkaitan erat dengan lingkungan fisik. Elemen penting dalam behavior setting meliputi sekelompok orang sebagai pelaku aktivitas, perilaku atau aktivitas, tempat terjadinya aktivitas, serta waktu spesifik saat aktivitas tersebut berlangsung. Analisis behavior setting dapat dilakukan melalui Behavior Mapping. Tujuannya adalah untuk menggambarkan perilaku dalam peta, mengidentifikasikan jenis dan frekuensi perilaku, serta menunjukkan kaitan antara perilaku tersebut dengan wujud perancangan yang spesifik. Terdapat dua cara untuk melakukan pemetaan perilaku menurut Sommer, 1980 dalam (Setiawan, 1995) yakni Place-centered mapping dan Personcentered mapping. Place-centered mapping adalah teknik yang digunakan untuk mengetahui bagaimana manusia atau sekelompok manusia memanfaatkan, menggunakan dan mengakomodasikan perilakunya dalam suatu waktu pada tempat tertentu. Personcentered mapping yaitu teknik yang menekankan pada pergerakan manusia pada periode waktu tertentu, dimana teknik ini berkaitan dengan tidak hanya satu tempat atau lokasi akan tetapi beberapa tempat / lokasi. Pada teknik ini peneliti berhadapan dengan seseorang yang khusus diamati.

\section{METODE}

Pada penelitian ini, metode penelitian yang digunakan adalah deskriptif kuantitatif dan kualitatif, dimana di dalamnya terdapat variabel-variabel yang dapat diukur dan dideskripsikan. Fokus utama dari penelitian ini adalah untuk mengidentifikasi perilaku masyarakat di ruang terbuka publik Alun-Alun Kabupaten Blora. Analisis yang dilakukan dalam penelitian ini meliputi analisis karakteristik pengunjung, analisis karakterisitk aktivitas, analisis pola pergerakan pengunjung, serta analisis perilaku pengunjung dalam menggunakan ruang terbuka publik alun-alun Kabupaten Blora. Teknik pengumpulan data yang digunakan berupa observasi lapangan, kuesioner, dan wawancara terhadap pengunjung. Teknik analisis data hasil penelitian menggunakan analisis statistik deskriptif dan analisis behavior setting. Analisis behavior setting digunakan untuk menganalisis pola pergerakan yang disajikan dalam bentuk peta berupa person-centerd mapping dan placecentered mapping.

Sementara itu teknik sampling yang digunakan adalah Probability Sampling dengan variasi sampling stratifikasi (Stratified Sampling) untuk observasi dan sampling acak sederhana (Simple Random Sampling) untuk kuesioner dan wawancara. Untuk sampling observasi lapangan, sampling dibagi dalam kelompok anak-anak, remaja, dan dewasa dengan proporsi jumlah yang sama yakni 2 orang untuk tiap kelompok pada waktu pengamatan yang berbeda-beda. Waktu pengamatan terdiri dari pagi sampai siang hari biasa, pangi sampai siang hari libur, sore sampai malam hari biasa, dan sore sampai malam hari libur. Sedangkan jumlah sampling untuk kuesioner berjumlah 100 responden, yang didapat dari perhitungan Rumus Slovin.

\section{HASIL DAN PEMBAHASAN}

\section{Analisis Karakterisitik Pengunjung}

Karakteristik pengunjung yang datang bermacam-macam, mulai dari umur, status pekerjaan, tujuan kunjungan, dan lain sebagainya tentunya berbeda-beda satu sama lain. Sebagian besar pengunjung datang bersama teman atau keluarga. Alat transportasi yang sering digunakan adalah motor yaitu hampir $80 \%$, lainnya adalah mobil, sepeda serta alat transportasi lainnya. Tujuan utama pengunjung pergi ke alun-alun adalah untuk nongkrong (berkumpul) bersama teman ataupun keluarga sambil makan, jalan-jalan, serta bermain 
bagi anak-anak. Lama waktu yang dihabiskan pengunjung dalam satu kali kunjungan cenderung lama, sekitar 30 menit sampai lebih dari 1 jam. Berdasarkan intensitas kunjungan, sebagian besar pengunjung jarang mengunjungi alun-alun. Banyak pula yang cukup sering berkunjung, bisa 1 atau 2 kali dalam seminggu. Sementara itu sebagian sering berkunjung hingga lebih dari 3 kali dalam seminggu, yang biasanya adalah pengunjung yang rumahnya dekat denga alun-alun .

\section{Analisis Karakterisitik Aktivitas}

Berdasarkan analisis karakteristik aktivitas, terdapat banyak jenis aktivitas umun pengunjung selain aktivitas utama (berkumpul, bermain, makan, olahraga), yaitu bermian HP, berfoto, merokok, duduk, berjalan, membuang sampah, dan lain sebagainya. Aktivtas pengunjung yang berlangsung pada pagi sampai siang hari pada hari biasa cenderung hanya sedikit karena tidak banyak yang berkunjung pada waktu tersebut, aktivitas yang dilakukan hanya sekedar duduk-duduk sambil ngobrol. Berbeda dengan kondisi tersebut, aktivitas yang berlangsung pada pagi sampai siang hari pada hari libur sangat beragam karena banyak pengunjung yang datang untuk berolahraga sambil jalan-jalan pada hari minggu pagi saat kegiatan CFD (Car Free Day). Hampir seluruh jenis pengunjung dengan usia dan status yang bermacam-macam datang pada hari minggu pagi, serta kegiatan yang dilakukan tidak hanya olahraga saja, banyak pula yang berjualan makanan/sarapan pagi yang membuat pengunjung semakin ramai. Sementara itu pada sore hingga malam hari aktivitas yang dilakukan hampir sama, dengan kegiatan utama nongkrong, makan, dan bermain anak.

\section{Analisis Pola Pergerakan Pengunjung}

Analisis pola pergerakan menjelaskan pergerakan pengunjung dan aktivitas yang dilakukan pengunjung beserta tempatnya melakukan aktivitas. Berikut merupakan hasil analisis pola pergerakan pengunjung alun-alun berdasarkan rentan waktu yang berbeda-beda.

1. Pagi sampai Siang Hari Biasa

Sangat sedikit pengunjung alun-alun Kabupaten Blora yang datang pada pagi sampai siang hari saat hari biasa. Pergerakan yang dilakukan juga tidak banyak, hanya berada di sekitaran tempat duduk yang disediakan. Pengunjung cenderung masuk dari sisi utara dan sisi barat. Pengunjung yang masuk dari sisi utara sebagian besar memarkirkan kendaraannya di dalam alun-alun berdekatan dengan area yang ingin di tuju. Sedangakan pengunjung yang masuk dari tangga barat akan memarkirkan kendaraannya di depan indomaret yang berada di sebrang barat alun-alun. Pengunjung cenderung hanya dudukduduk sambil mengobrol atau memainkan HP.

2. Pagi sampai Siang Hari Libur

Pengunjung yang datang ke alun-alun Kabupaten Blora pada pagi sampai siang hari saat hari libur sangat banyak. Sebagian besar pengunjung datang untuk berolahraga, dari mulai jogging, lari, bersepeda, sampai dengan bermain basket, skateboard, dan sepatu roda. Tersedia pula arena bermain bagi anak-anak yang biasanya dibuka hanya saat malam hari. Banyak pula penjualan makanan untuk sarapan yang menjajakan makanannya di pinggiran jalan sekeliling alun-alun. Pengunjung yang membawa kendaraan bermotor memarkirkan kendaraannya di luar jalan yang mengelilingi alun-alun, area parkir yang disediakan ada di sebelah utara, selatan, dan barat alun-alun. Pergerakan sangat padat karena banyak yang berjalan mengelilingi alun-alun.

3. Sore sampai Malam Hari Biasa

Pada saat sore hingga malam hari, hampir semua pinggiran alun-alun diisi oleh tempat berjualan makanan yang beraneka ragam. Ada pula beberapa penjual makanan yang berjualan di seberang jalan alun-alun. Cukup banyak pengunjung anak-anak yang 
datang untuk bermain permainan anak. Banyak pula pengunjung remaja dan dewasa yang datang untuk nongkrong bersama teman-teman atau keluarganya di area lesehan sekeliling jalur pejalan kaki. Pergerakan pengunjung tergolong sederhana saja sesuai dengan keperluan penggunanya. Jalur pejalan kaki di sekeliling alun-alun menjadi agak susah untuk dilewati karena sebagian digunakan untuk lapak-lapak penjual makanan senagai tempat duduk lesehan

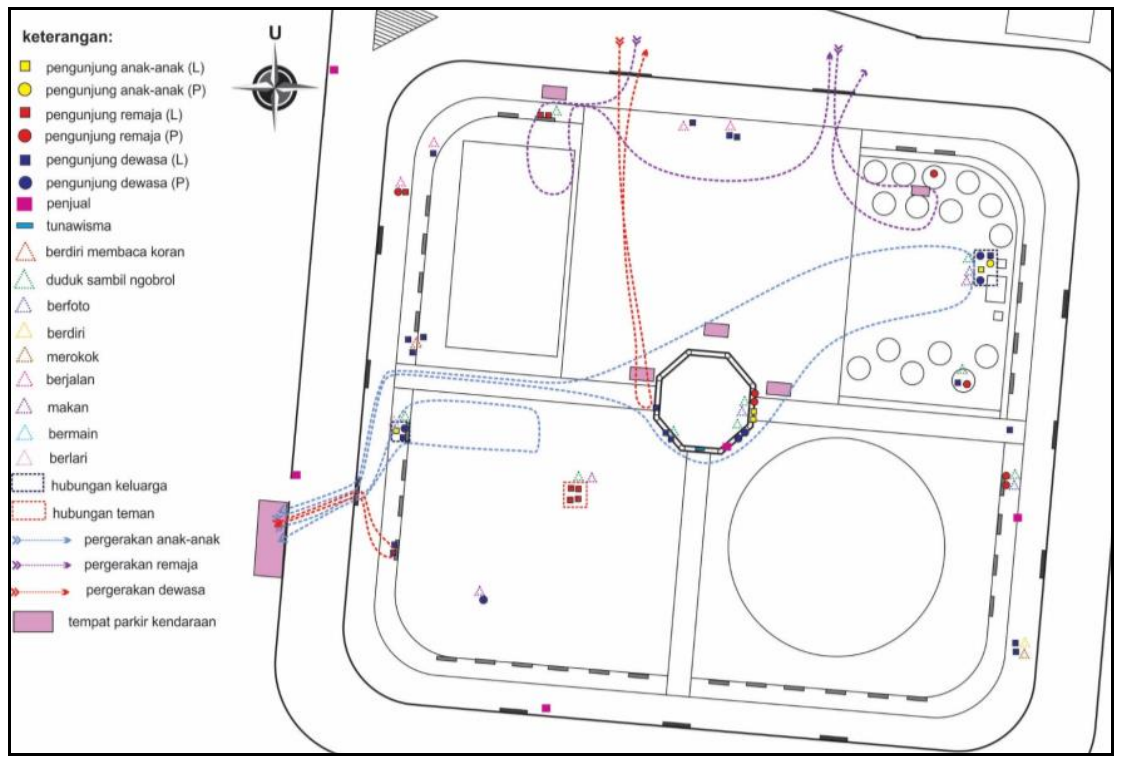

Sumber: Hasil Analisis Penulis, 2018

Gambar 1. Pola Pergerakan Pengunjung pada Pagi sampai Siang Hari Biasa

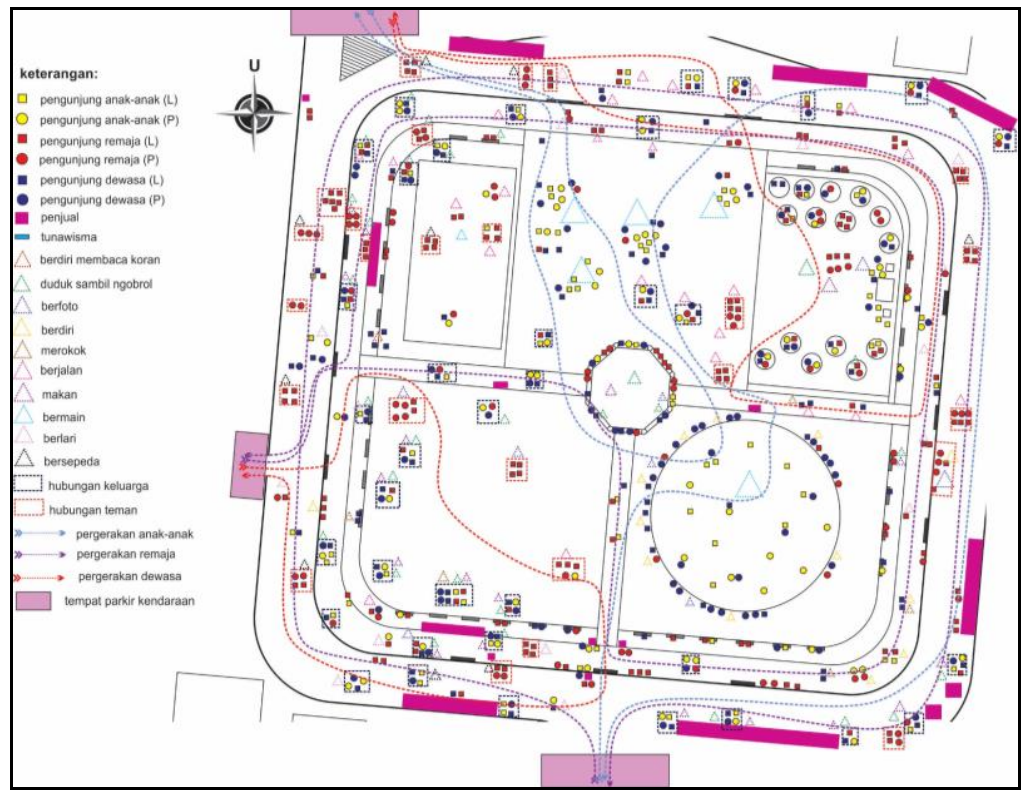

Sumber: Hasil Analisis Penulis, 2018

Gambar 2. Pola Pergerakan Pengunjung pada Pagi sampai Siang Hari Libur 


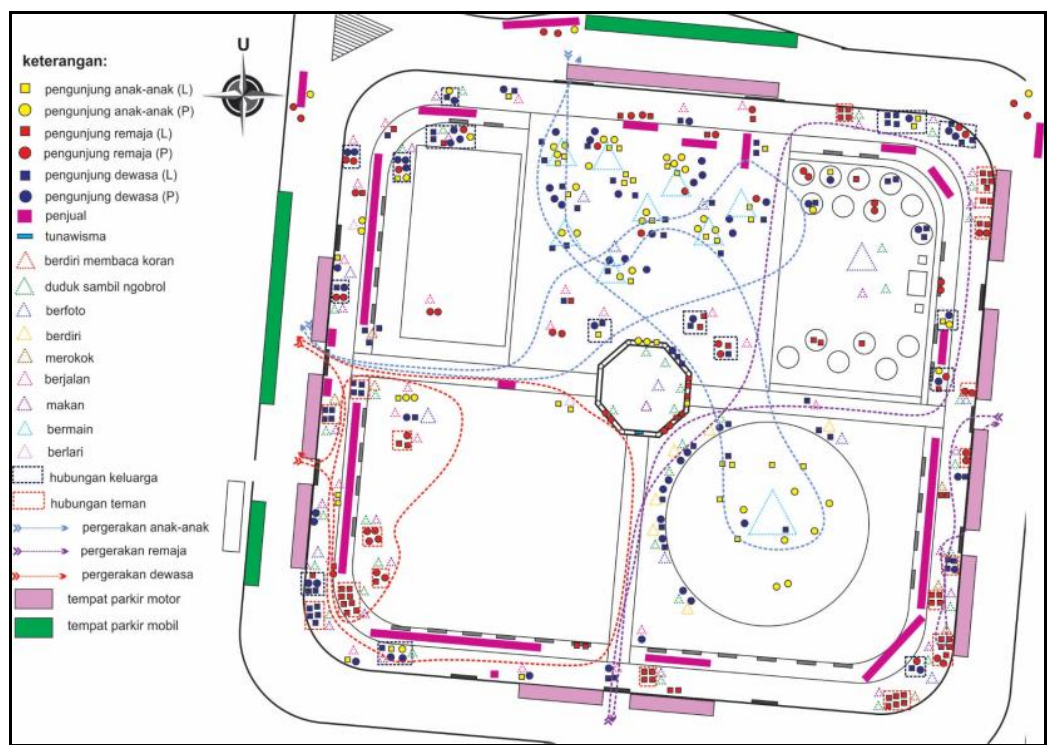

Sumber: Hasil Analisis Penulis, 2018

\section{Gambar 3. Pola Pergerakan Pengunjung pada Sore sampai Malam Hari Biasa}

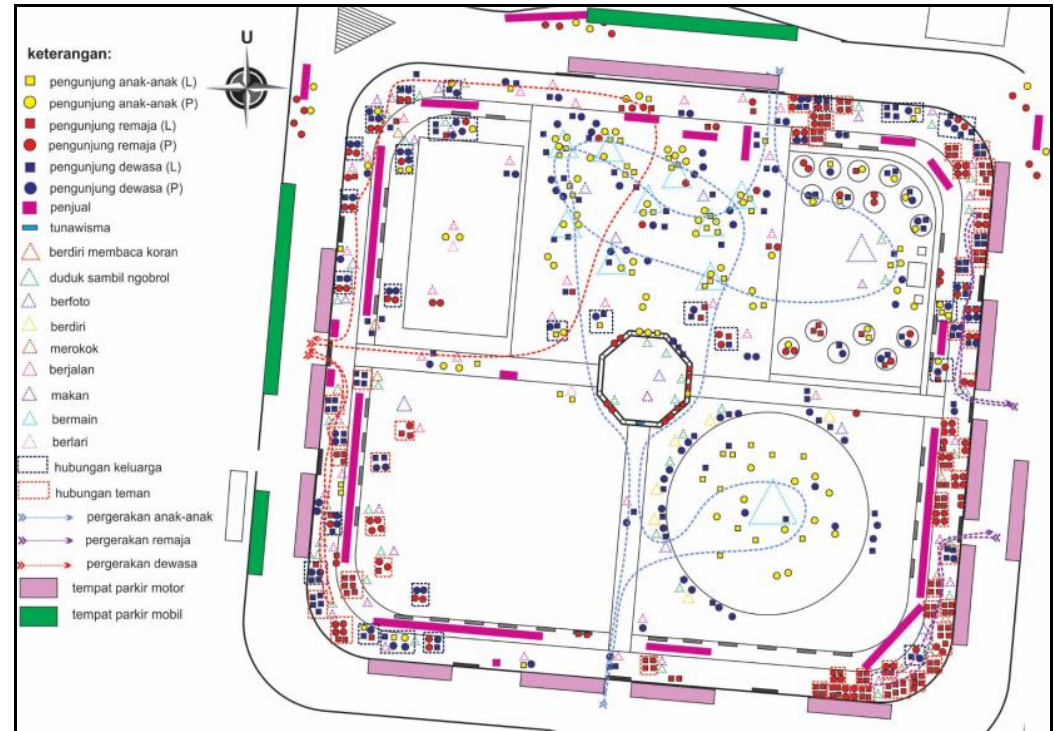

Sumber: Hasil Analisis Penulis, 2018

\section{Gambar 4. Pola Pergerakan Pengunjung pada Sore sampai Malam Hari Libur}

\section{Sore sampai Malam Hari Libur}

Pada sore sampai malam hari saat hari libur, alun-alun sangat ramai oleh pengunjung, jika dibandingkan dengan sore hingga malam pada hari biasa cukup berbeda karena jauh lebih ramai. Tatanan tempat berjualan sama seperti hari-hari biasanya, hanya bertambah lebih banyak penjual dan area duduk lesehannya. Sedangkan pengunjung yang semakin bertambah banyak adalah golongan remaja yang datang untuk nongkrong bersama teman-temannya. Pengunjung usia remaja bahkan hampir memenuhi seluruh area jalur pejalan kaki di sebelah timur alun-alun. Pergerakan pengunjung tergolong sederhana saja sesuai dengan keperluan tempat yang dituju penggunanya. Jalur pejalan kaki hampir di semua ruas penuh dengan pengunjung yang duduk di tempat duduk lesehan, sehingga 
untuk pergerakan berjalan di jalur pejalan kaki yang mengelilingi alun-alun hampir tidak mungkin.

\section{Analisis Perilaku Masyarakat Pengguna Alun-Alun}

1) Kenyamanan Fasilitas

Kenyamanan fasilitas tempat duduk, meja, dan tangga berdasarkan standar ukurannya sebagian besar sudah sesuai namun ada beberapa tempat duduk yang ukurannya kurang sesuai dan beberapa ruas tangga yang terlalu curam. Bagi sebagian besar pengunjung beranggapan fasilitas yang tersedia sudah nyaman, dengan ukuran yang pas, layak digunakan, dan tidak ada gangguan saat digunakan. Besar kemungkinan jawaban tersebut kurang valid, karena pengunjung merasa sudah terbiasa dengan kondisi fasilitas yang demikian sehingga merasa baik-baik saja dengan hal tersebut. Ada pula beberapa pengunjung yang merasa kurang nyaman dengan fasilitas yang terssedia, diantaranya dikarenakan terkadang kotor akibat bekas dipakai untuk lapak berjualan, serta kursi gazebo yang kurang nyaman karena mudah rusak dan mudah dipindahkan.

2) Sosialitas antar Pengunjung

Kemauan pengunjung untuk bersosialisasi dengan orang lain tergolong tinggi, sesuai dengan fungsi ruang terbuka publik untuk bersosialisasi. Namun, kemauan berhubungan dengan orang lain cenderung hanya dengan orang yang dikenal saja, sementara dengan orang lain yang tidak dikenal masih kurang peduli.

3) Visibilitas Terhadap Objek yang Dituju

Visibilitas berkaitan dengan kemudahan pengunjung untuk melihat objek yang akan dituju. Sebagian besar pengunjung beranggapan dapat melihat dengan jelas objek yang ingin dituju tanpa halangan apapun. Sementara itu ada pula yang beranggapan terhalang oleh beberapa objek lain, yaitu pedagang kaki lima, pohon, tiang, dan kerumunan orang.

4) Aksesibilitas Pengunjung

Aksesibilitas dibagi menjadi aksesibilitas jalan dan aksesibilitas jalur pejalan kaki. Aksesibilitas jalan menunjukkan fungsi jalan sebagai Akses Lalu Lintas, Tempat Parkir, dan Penyebrangan Bagi Pejalan Kaki. Aksesibilitas jalur pejalan kaki berisi atribut-atribut yang dapat mempengaruhi kemudahan dalam mengakses jalur pejalan kaki.

Jalan sebagai akses lalu lintas kondisinya sudah baik, tidak ada ruas jalan yang berlubang, kondisi pencahayaan jalan pada malam hari juga sudah baik. Sementara itu, jalan yang mengelilingi alun-alun juga dimanfaatkan untuk parkir kendaraan khususnya pada saat malam hari di kiri dan kanan jalan. Parkir di kana jalan cenderung agak sulit karena harus membelokkaan kendaraan ke kanan terlebih dahulu, namun ada petugas parkir yang membantu pengunjung untuk memarkirikan kendaraan. Tempat parkir yang paling ramai adalah bagian timur dan bagian barat. Banyak pengunjung yang perlu menyebrang menuju alun-alun karena tempat parkirnya di kiri jalan, jika ingin masuk alunalun harus menyebrang terlebih dahulu. Sebagian besar merasa mudah untuk menyebrang, namun ada pula yang kesusahan menyebrang karena arus lalu lintas terlalu ramai. Oleh karena itu, sebagian besar pengunjung merasa perlu penambahan jalur penyebrangan agar lebih aman dan mudah.

Sementara itu jalur pejalan kaki lebarnya sudah mencukupi untuk kebutuhan pergerakan pejalan kaki. Kondisi penerangan jalan dan pohon peneduh juga dinilai cukup baik, meskipun beberapa titik masih kurang. Belum terdapat jalur khusus difabel, sehingga pengunjung merasa perlu ditambahkan agar oengunjung dengan kebutuhan khusus bisa menggunakannya. Pada akses jalur pejalan kaki selalu terganggu oleh lapak penjual makanan yang menggunakan area jalur pejalan kaki sebagai tempat berjualan, sehingga sirkulasi menjadi terganggu dan tidak banyak pengunjung yang menggunkaan jalur pejalan kaki sebagaimana mestinya. 
5) Adaptabilitas Pengunjung

Adaptasi pengunjung terhadap kondisi alun-alun saat sedang sangat ramai, sebagian besar pengunjung beradaptasi dengan berusaha tetap menikmatinya dan tidak merasa terganggu, sehingga lebih memilih untuk tetap tinggal dan melakukan aktivitas yang diinginkan. Sementara itu dalam kaitannya terhadap kondisi tempat duduk yang kurang nyaman saat digunakan, sebagian besar pengunjung beradaptasi dengan tidak menggunakan tempat duduk, kemudian lebih memilih mencari tempat duduk lain yang dianggap lebih sesuai.

6) Rangsangan Inderawi

Dalam kaitannya dengan pencahayaan, pengunjung lebih menyukai cahaya lampu yang terang daripada cahaya lampu yang agak redup karena akan terasa lebih aman dan aktivitas mudah untuk dikontrol. Sementara itu terhadap suara kebisingan lalu lintas dan suara sekitar sebagian merasa terganggu, namun banyak yang memaklumi karena alunalun merupakan ruang publik yang ramai. Sedangkan terdadap bau tidak sedap, banyak pengunjung merasa terganggu dengan bau tidak sedap pada waktu-waktu tertentu.

7) Aktivitas dan Kontrol

Setiap area (teritori) tertentu yang terdapat di dalam alun-alun sudah dilengkapi dengan kontrol yang baik berupa pembatas di setiap sudut area untuk membatasi teritori yang satu dengan teritori yang lain. Seperti halnya antara jalur pedestrian dengan jalan raya dibatasi dengan ketinggian yang berbeda, saluran drainase, dan beberapa pot tanaman. Dengan adanya kontrol pada setiap teritori dapat mempermudah pelaksanaan aktivitas-aktivitas tertentu yang membutuhkan cakupan ruang yang berbeda-beda.

8) Kesesakan dan Privasi

Saat kondisi alun-alun sedang sangat ramai oleh pengunjung, sebagian besar tidak terlalu merasakan kesesakan. Tingkat kesesakan masing-masing pengunjungberbeda-beda, ada yang merasa sesak, ada pula yang biasa saja saat mendapati kondisi yang ramai. Pengunjung merasa terganggu dengan banyaknya pengamen dan pengemis yang memintaminta pada saat alun-alun sedang ramai pengunjung. Hal tersebut dapat mengganggu privasi pengunjung saat sedang berktivitas dengan tenang.

9) Makna dan Legibilitas

Alun-alun Kabupaten Blora memiliki makna yang kuat bagi pengunjung. Hal-hal yang selalu diingat oleh pengunjung mengenai alun-alun beberapa diantaranya adalah pohon beringin yang berada tepat di tengah alun-alun yang sudah ada sejak dahulu kala, banyak tempat makan di alun-alun yang menjadi favorit sebagian pengunjung, terdapat tempat bermain anak, beberapa fasilitas yang tersedia, serta dekat dengan berbagai fasilitas umum seperti masjid, bank, dan gedung pertemuan. Ada pula yang memaknai alun-alun karena hal-hal yang bersifat negatif, yaitu banyaknya pengamen dan pengemis yang selalu ada saat alun-alun sedang ramai pengunjung. Sebagian besar pengunjung sudah sering datang ke alun-alun sehingga sudah sangat paham alur dan jalan yang terdapat di dalam ruang alun-alun, sehingga tidak akan kesulitan untuk menemukan tempat yang ingin dituju.

\section{KESIMPULAN}

Perilaku yang dilakukan oleh masyarakat pengunjung alun-alun sebagian besar dipengaruhi oleh kondisi kualitas lingkungan, serta kondisi diri pribadi masing-masing individu yang dipengaruhi oleh banyak faktor dari luar maupun dari dalam. Antara perilaku yang satu dengan perilaku yang lain saling berkaitan dan membentuk pola perilaku. Banyak ditemukan pola perilaku yang berbeda-beda pada pengunjung alun-alun Kabupaten Blora. Alun-alun sebagai sarana sosial kemasyarakatan menampung banyak orang dengan kriteria yang berbeda-beda, aktivitas yang dilakukan juga berbeda-beda, namun sama-sama bertujuan berinteraksi dengan orang lain. Perilaku yang menyimpang disebabkan karena 
penggunaan ruang yang tidak sesuai dengan fungsi aslinya, serta melampaui batas teritori ruang sehingga bersinggungan dengan teritori untuk kegiatan lainnya. Hal tersebut dapat berpengaruh buruk terhadap keberlangsungan kondisi lingkungan. Oleh karena itu penataan seting lingkungan dapat dilakukan untuk mengubah perilaku yang menyimpang menjadi kebiasaan perilaku yang baik.

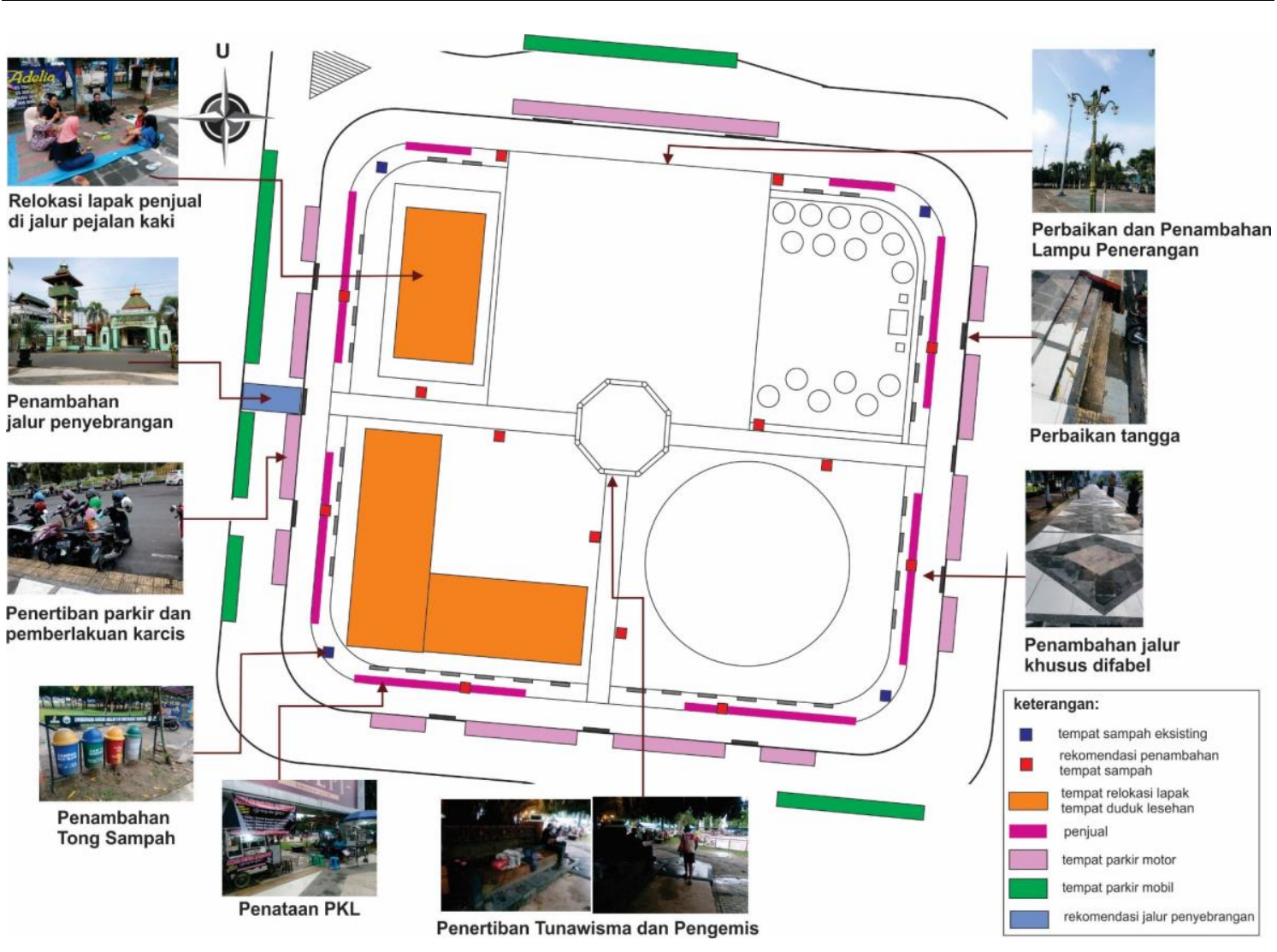

Sumber: Hasil Analisis Penulis, 2018

\section{Gambar 5. Pola Pergerakan Pengunjung pada Sore sampai Malam Hari Biasa}

\section{DAFTAR PUSTAKA}

Carr, S. (1992). Environment and Behavior Series Public Space. Australia: Press Syndicate of University of Cambridge.

Damayanty, N., Izziah, \& Anggraini, R. (2018). KAJIAN KESESUAIAN PENATAAN RUANG TERBUKA PUBLIK DI KAWASAN PASAR ACEH KOTA BANDA ACEH DENGAN KOMPONEN DAN INDIKATOR PERANCANGAN TAMAN KOTA SERTA RTRW KOTA BANDA ACEH 2009-2029. Jurnal Arsip Rekayasa Sipil Dan Perencanaan, 1(1), 53-62.

Effendi, D., Waani, J. O., \& Sembel, A. (2016). POLA PERILAKU MASYARAKAT TERHADAP PEMANFAATAN RUANG TERBUKA PUBLIK DI PUSAT KOTA TERNATE. E-Journal Universitas Sam Ratulangi, 185-197.

Liao, T. F., Rule, A., Ardisana, R., Knitcher, A., Mayo, A., \& Sarcu, C. (2012). Social Behavior in Public Spaces in a College Town. Sociologija i Prostor, 56(773), 3-27. https://doi.org/10.5673/sip.50.1.1

Notoadmodjo, S. (2007). Promosi Kesehatan dan Ilmu Perilaku.

Setiawan, H. B. (1995). Arsitektur Lingkungan dan Perilaku. Yogyakarta: Direktorat Jendral Pendidikan.

Vertelj Nared, P., \& Zavodnik Lamovšek, A. (2015). Public Open Space as a Contribution to Urban Development in Small Slovenian Cities. Urbani Izziv, 26(supplement). https://doi.org/10.5379/urbaniizziv-en-2015-26-supplement-008

Winardi, J. (2004). Manajemen Perilaku Organisasi. Jakarta: Kencana. 